\title{
Disturbed Copper Bioavailability in Alzheimer's Disease
}

\author{
Daniela Kaden, ${ }^{1}$ Ashley I. Bush, ${ }^{2}$ Ruth Danzeisen, ${ }^{3}$ Thomas A. Bayer, ${ }^{4}$ and Gerd Multhaup ${ }^{1}$ \\ ${ }^{1}$ Institute of Chemistry and Biochemistry, Freie Universität Berlin, Thielallee 63, 14195 Berlin, Germany \\ ${ }^{2}$ The Mental Health Research Institute, The University of Melbourne, 155 Oak Street, Parkville, VIC 3052, Australia \\ ${ }^{3}$ International Copper Association, 260 Madison Avenue, Floor 16, New York, 10016 NY, USA \\ ${ }^{4}$ Division of Molecular Psychiatry, Georg-August-University Göttingen, University Medicine Göttingen, 37075 Göttingen, Germany
}

Correspondence should be addressed to Ruth Danzeisen, rdanzeisen@copper.org

Received 15 June 2011; Revised 19 August 2011; Accepted 20 August 2011

Academic Editor: Rosanna Squitti

Copyright ( 2011 Daniela Kaden et al. This is an open access article distributed under the Creative Commons Attribution License, which permits unrestricted use, distribution, and reproduction in any medium, provided the original work is properly cited.

Recent data from in vitro, animal, and human studies have shed new light on the positive roles of copper in many aspects of AD. Copper promotes the non-amyloidogenic processing of APP and thereby lowers the A $\beta$ production in cell culture systems, and it increases lifetime and decreases soluble amyloid production in APP transgenic mice. In a clinical trial with Alzheimer patients, the decline of $\mathrm{A} \beta$ levels in CSF, which is a diagnostic marker, is diminished in the verum group ( $8 \mathrm{mg}$ copper/day), indicating a beneficial effect of the copper treatment. These observations are in line with the benefit of treatment with compounds aimed at normalizing metal levels in the brain, such as PBT2. The data reviewed here demonstrate that there is an apparent disturbance in metal homeostasis in AD. More research is urgently needed to understand how this disturbance can be addressed therapeutically.

\section{Copper: Essential and Potentially Toxic}

Copper is needed by every oxygen-requiring cell and can be toxic in excess. It is an essential metal with extremely complex roles in numerous different biological functions from acute phase reactant to mitochondrial energy generation. $\mathrm{Cu}$ levels are very tightly regulated on the level of duodenal absorption as well as uptake into cells or excretion from cells. Intracellularly, it is transported by specialized chaperonelike proteins to protect the ion from reactions with reactive oxygen species [1].

Plasma $\mathrm{Cu}$ levels do not correspond to an individual's $\mathrm{Cu}$ exposure or $\mathrm{Cu}$ status. $\mathrm{Cu}$ serum levels rise during acute phase, they correlate positively with estrogen levels, and can also rise during many chronic disease states. This is caused by an increase in a $\mathrm{Cu}$-containing plasma protein called ceruloplasmin (Cp). Most of the plasma $\mathrm{Cu}$ is bound to $\mathrm{Cp}$ (up to $95 \%$ ), with the remaining portion of the $\mathrm{Cu}$ being bound to albumin or histidine residues in other proteins [2].

A possible role of $\mathrm{Cu}$ in $\mathrm{AD}$ has remained a contentious topic during the past 15 years, as has been the question whether extracellular amyloid deposited in plaques is the causative agent in $\mathrm{AD}$. The scientific community was divided as to whether $\mathrm{Cu}$ has a role at all, and-if yes—whether it is friend or foe.

Intensive basic research has led to a paradigm shift in both unveiling a beneficial role for $\mathrm{Cu}$ in $\mathrm{AD}$ on the one hand and deleterious functions of lower intracellular amyloid oligomers consisting of the 42 amino acid residue amyloid- $\beta$ peptide $(\mathrm{A} \beta 42)$.

\section{Copper and Alzheimer's Disease: Molecular and In Vitro Findings}

On a molecular level, interactions between $\mathrm{Cu}$ and proteins involved in $\mathrm{AD}$ are observed, that is, the amyloid precursor protein (APP), the beta-site APP-cleaving enzyme 1 (BACE1), and the $\mathrm{A} \beta$ peptide. APP has a role in $\mathrm{Cu}$-efflux [3] and binds $\mathrm{Cu}(\mathrm{II})$ via its extracellular domain $[4,5]$, where bound $\mathrm{Cu}(\mathrm{II})$ is reduced to $\mathrm{Cu}(\mathrm{I})[6,7]$. Additionally, APP trafficking is directly influenced by $\mathrm{Cu}$. Cu treatment of neuronal cells revealed an increase of APP at the cell surface by both promoting its exocytosis from the Golgi and by reducing its rate of endocytosis $[8,9]$. BACE1 is an aspartic protease, cleaving APP in the first step of $A \beta$ generation. 
BACE1 binds a single $\mathrm{Cu}(\mathrm{I})$ atom with high affinity through cysteine residues of its $\mathrm{C}$-terminal domain and interacts with the cytoplasmic $\mathrm{Cu}$-chaperone CCS (the $\mathrm{Cu}$ chaperone for $\mathrm{Cu}, \mathrm{Zn}$-superoxide dismutase (SOD1)) through domain I [10]. $\mathrm{A} \beta$, which is part of the ectodomain and the transmembrane segment of APP, was also shown to bind $\mathrm{Cu}$, and $\mathrm{Cu}$ was found enriched in plaque deposits which mainly consist of $\mathrm{A} \beta$ [11-14]. Thus, APP, BACE1, and $\mathrm{A} \beta$ are metalloproteins which can bind $\mathrm{Cu}$ and were experimentally shown to be involved in brain $\mathrm{Cu}$ homeostasis.

In 1994, the aggregation of synthetic $\mathrm{A} \beta$ peptides into assemblies of oligomers and fibrils upon binding of $\mathrm{Cu}$ (II) was reported [15]. It was the time before the toxicity of lower $\mathrm{A} \beta$ oligomers was discovered and insoluble plaque amyloid was found inert [16]. Over the years, the hypothesis of oligomers as causative agents was confirmed [17]. Recent research has provided evidence that oligomers were shown to induce hyperphosphorylation of tau at $\mathrm{AD}$-relevant epitopes in hippocampal neurons, and thereby provided a strong link between the pathological hallmarks of $\mathrm{A} \beta$ and tau deposits [18]. Oligomers isolated from the $\mathrm{AD}$ brain were found to potently induce AD-type tau phosphorylation. Tau was found to form $\mathrm{Cu}$-complexes with one $\mathrm{Cu}$ (II) ion bound per monomer with a dissociation constant in the micromolar range $\mathrm{Cu}(\mathrm{II})$, having an inhibiting effect on the in vitro aggregation of tau $[19,20]$. However, since tau occurs intracellularly and $\mathrm{Cu}$ (II) is mainly found in the extracellular space, the likelihood that this reflects a physiological function is low.

Findings such that human $\mathrm{A} \beta$ directly produces hydrogen peroxide $\left(\mathrm{H}_{2} \mathrm{O}_{2}\right)$ by a mechanism that involves the reduction of metal ions, $\mathrm{Fe}$ (III) or $\mathrm{Cu}(\mathrm{II})$, setting up conditions for Fenton-type chemistry [21] or that $\mathrm{Cu}(\mathrm{II})$ and $\mathrm{Zn}$ (II) inhibit A $\beta$ fibrillization $[22,23]$ were all generated by in vitro assays and were never systematically addressed by in vivo model systems.

\section{Copper and Alzheimer's Disease: Findings in Animal Models}

Maynard et al. have shown that overexpression of the carboxy-terminal fragment of APP which contains the A $\beta$ sequence elicits significantly reduced $\mathrm{Cu}$ levels in transgenic mouse brains [24]. Importantly, animal model systems of $\mathrm{AD}$ and studies with living cells revealed that APP is actively involved in balancing $\mathrm{Cu}$ concentrations. In APP and APLP2 knockout mice, $\mathrm{Cu}$ levels were found increased in cerebral cortex and liver [25], whereas overexpression of APP was reported to result in significantly reduced $\mathrm{Cu}$ levels in the brain of three transgenic mouse lines [24, 26].

APP23 mice (expressing human APP751 with the Swedish mutation) have amyloidogenic deposits after 6 months and more than half of the population dies before the age of 18 months. Treatment with clioquinol, a hydrophobic lowaffinity $\mathrm{Cu}$, and zinc chelator had a significant benefit in this $\mathrm{AD}$ mouse model by normalizing, which is elevating, brain $\mathrm{Cu}$ and zinc levels. In the treated animals brain, $\mathrm{A} \beta$ deposition was decreased, and the general health of the animals was improved [27].
A later study in two different strains of amyloid-bearing transgenic mice confirmed the cognitive benefits of clioquinol treatment [28]. Treatment with clioquinol's secondgeneration analogue, PBT2, rapidly restored cognition disturbances in $\mathrm{AD}$ transgenic mice and was associated with decreased interstitial $A \beta$ [29]. Further, the neurotrophic effects of PBT2 have recently been demonstrated to depend upon metal uptake [30].

Consistent with the above findings, a dietary treatment of APP23 transgenic mice with $\mathrm{Cu}$ sulfate for a 3-month interval extended the lifetime of the mice considerably and restored SOD-1 activity back to normal [26]. In agreement with the benefit of $\mathrm{Cu}$ treatment, $\mathrm{Cu}$ supplementation rescued premature death observed with clioquinol treatment of APP transgenic mice [31]. This is in contrast, however, to the above findings of benefits of clioquinol and PBT2 treatment.

Taken together, these observations indicate that restoring brain $\mathrm{Cu}$ homeostasis can have a beneficial effect on disease progression in mouse models for AD. Cu levels can be normalized by dietary treatment with bioavailable $\mathrm{Cu}$ salts, or by treatment with clioquinol, which normalizes $\mathrm{Cu}$ and zinc brain levels through the formation of metal-ion complexes which are transported across cellular membranes.

In contrast, another animal model, hypercholesterolemic rabbits, showed amyloid-inducing effects mediated by low $\mathrm{Cu}$ concentrations in drinking water $(0.12 \mathrm{mg} \mathrm{Cu} / \mathrm{L})$ [3234]. This effect was observed when $\mathrm{Cu}$ sulfate was added to distilled water, and not when tap water was used in combination with the high cholesterol feed [32]. Potable tap water typically contains at least this amount of $\mathrm{Cu}(0.12 \mathrm{mg} \mathrm{Cu} / \mathrm{L})$, present as $\mathrm{Cu}$ carbonate or $\mathrm{Cu}$ carbonate hydroxide. Also, when interpreting the findings in the hypercholesterolemic animals, it needs to be kept in mind that high cholesterol levels itself show $\mathrm{A} \beta$-elevating effects [35].

\section{Copper and Alzheimer's Disease: Human Trials}

Based on the animal study [26], oral intake of $\mathrm{Cu}$ (II) in $\mathrm{AD}$ patients was investigated in a clinical trial. The efficacy of oral $\mathrm{Cu}$ supplementation in the treatment of $\mathrm{AD}$ patients was evaluated for 12 months in a prospective, randomized, double-blind, placebo-controlled phase 2 clinical trial in patients with mild AD. Sixty-eight subjects were randomized. Patients with mild $\mathrm{AD}$ received either $\mathrm{Cu}$-(II)-orotate-dihydrate (verum group; $8 \mathrm{mg} \mathrm{Cu}$ daily) or placebo (placebo group). CSF was collected at beginning and at the end of the study after 12 months. The treatment was well tolerated. The primary outcome measures in CSF were A $\beta 42$, Tau, and Phospho-Tau. $\mathrm{Cu}$ intake had no effect on the progression of Tau and Phospho-Tau levels in CSF [36].

While A $\beta 42$ levels declined by $30 \%$ in the placebo group $(P=0.001)$, they decreased only by $10 \%(P=0.04)$ in the verum group [36]. Since decreased CSF A $\beta 42$ is a diagnostic marker for $\mathrm{AD}$, this observation indicated that $\mathrm{Cu}$ treatment had a positive effect on a relevant $\mathrm{AD}$ biomarker. There were, however, no significant differences in primary outcome measures (AD Assessment Scale, Cognitive subscale (ADAScog), Mini Mental Status Examination) between the 
verum and the placebo group [37]. Finally, CSF A $\beta 42$ levels declined significantly in both groups within 12 months supporting the notion that CSF A $\beta 42$ may be valid not only for diagnostic but also for prognostic purposes in $\mathrm{AD}$ [36].

Plasma $\mathrm{Cu}$ levels declined only in the placebo group during the 12-month period. However, the outcome of the randomization was such that the placebo group had higher $\mathrm{Cu}$ levels at the beginning of the study. Cu levels in the verum group were unchanged, which seems to be paradoxical. One may speculate that $\mathrm{Cu}$ treatment normalized $\mathrm{Cu}$ levels in plasma in the verum group by enhanced uptake and transport and improved tissue homeostasis.

Previously, we have reported that significantly lower levels of $\mathrm{Cu}$ in plasma were found in those $\mathrm{AD}$ patients, who fulfilled the criteria of CSF diagnosis for AD [38]. In addition, we observed reduced $\mathrm{Cu}$ levels in plasma in patients with higher ADAScog scores (making more mistakes in this neuropsychological test) [39]. However, $\mathrm{Cu}$ treatment had no beneficial effect on cognitive abilities in $\mathrm{AD}$ patients of the present clinical phase II pilot study [37]. There was no correlation between plasma or CSF Cu and cholesterol levels.

The $\mathrm{Cu}$-clinical trial demonstrates that long-term oral intake of $8 \mathrm{mg} \mathrm{Cu}$ (Cu-(II)-orotate-dihydrate) can be excluded as a risk factor for $\mathrm{AD}$, and-based on the CSF biomarker analysis-that $\mathrm{Cu}$ may potentially play a beneficial role in this disease.

This is consistent with findings from a pilot phase II clinical trial, where the placebo group deteriorated faster than the clioquinol-treated group suggesting a beneficial effect of clioquinol treatment [40]. In line with these observations, treatment of AD patients with PBT2 in a phase IIa, doubleblind, randomized, placebo-controlled trial, PBT2 induced a significant improvement in cognitive performance after 12 weeks without changing plasma $\mathrm{Cu}$ levels [41].

Although we found beneficial effects of $\mathrm{Cu}$, there are contradicting results showing that elevated free serum $\mathrm{Cu}$ levels (non-ceruloplasmin bound $\mathrm{Cu}$ ) might be a risk factor for $\mathrm{AD}$ [42-47]. A high proportion of the ceruloplasmin of these patients was enzymatically inactive [47], indicating that it contained less-than-normal $\mathrm{Cu}$. Ceruloplasmin is the main $\mathrm{Cu}$ carrier in plasma and has many roles, such as ferroxidase or acute phase reactant. However, ceruloplasmin is not a prerequisite for $\mathrm{Cu}$ delivery to the periphery [48]. The studies by Squitti, Arnal, and Brewer evaluating levels of non-ceruloplasmin $\mathrm{Cu}$ in $\mathrm{AD}$ patients do not indicate the chemical nature of this $\mathrm{Cu}$. It is, therefore, unclear whether or not this $\mathrm{Cu}$ is readily bioavailable or not. In any case, inactive ceruloplasmin and potentially less bioavailable "free" $\mathrm{Cu}$ will directly influence (i.e., lower) intracellular $\mathrm{Cu}$ levels and impair the functions of proteins using $\mathrm{Cu}$ as a cofactor.

"Free" $\mathrm{Cu}$ can have negative effects in the brain as seen in disease states like Wilsons disease. However, levels of $\mathrm{Cu}$ in CSF were not upregulated in $\mathrm{AD}$ as revealed in a metaanalysis [49]. Instead, the study of Kessler et al. revealed reduced plasma $\mathrm{Cu}$ and ceruloplasmin levels in patients with a CSF diagnosis of advanced $\mathrm{AD}$ which supports previous observations that a mild $\mathrm{Cu}$ deficiency might contribute to $\mathrm{AD}$ progression [38].
Whether the observed increase in the non-ceruloplasmin $\mathrm{Cu}$ portion is a cause or consequence of the $\mathrm{AD}$ pathogenesis also remains to be clarified. The conclusion that $\mathrm{Cu}$ intake or exposure can be a risk factor for $\mathrm{AD}$ cannot be drawn and a direct comparison between the work by Squitti et al and Brewer et al with an intervention study $(8 \mathrm{mg}$ Cu orotate per day, or treatment with PBT2) is difficult.

\section{Strategies to Rescue Copper Deficiency: Chelators, Ionophores, and Cu Nanocarriers}

APP and APLP2 extracellular domains, but not the extracellular domain of APLP1, decreased intracellular Cu levels in yeast cells and thus possess $\mathrm{Cu}$-efflux activities in this test system [3]. The addition of clioquinol-Cu complexes to the yeast culture medium drastically increased the intracellular $\mathrm{Cu}$ concentration, but there was no significant effect on zinc levels. This finding confirmed that facilitated metal-ion transport can act therapeutically by changing the distribution of $\mathrm{Cu}$ or facilitating $\mathrm{Cu}$ uptake rather than by decreasing $\mathrm{Cu}$ levels.

The expression of a mutant APP deficient for $\mathrm{Cu}$ binding increased intracellular $\mathrm{Cu}$ levels several fold [3]. These data not only uncovered a novel biological function for APP and APLP2 in cellular $\mathrm{Cu}$ homeostasis but also provided a new conceptual framework for the formerly diverging theories of $\mathrm{Cu}$ supplementation and chelation in the treatment of $\mathrm{AD}$ [27]. These results also strictly contradict a proposed metal chelation as a potential therapy for $\mathrm{AD}$ that was based on the $\mathrm{A} \beta$ interaction with transition metals [50].

Findings described above [3] and in the section of findings from animal models [31] encouraged us to address $\mathrm{Cu}-$ deficiency in $\mathrm{AD}$ by an aimed facilitation of $\mathrm{Cu}$ import into the brain of $\mathrm{Cu}$ deficient $\mathrm{AD}$ patients. Thus, several parameters have to be taken into consideration, and several requirements must be regarded. The transport and cellular metabolism of $\mathrm{Cu}$ depends on a series of membrane proteins and smaller soluble proteins that comprise a functionally integrated system for maintaining cellular $\mathrm{Cu}$ homeostasis.

Bypassing the cellular $\mathrm{Cu}$ uptake system would be a mean to achieve higher local concentrations compared to normal cellular uptake. We were able to show that synthetic substances called nanocarriers fulfill these requirements. They specifically transport $\mathrm{Cu}$ to intracellular regions and enrich local $\mathrm{Cu}$ concentrations (e.g. in endosomes versus cytosol) [51]. Cu released from the carrier was bioavailable and compensated decreased $\mathrm{Cu}$ levels in living cells. We and others showed earlier that high intracellular $\mathrm{Cu}$ levels stimulate the non-amyloidogenic pathway of APP processing, thereby, diminishing levels of toxic $A \beta$ peptides $[52,53]$. Vice versa, under conditions of low intracellular $\mathrm{Cu}$, APP proteolysis was shifted from non-amyloidogenic to amyloidogenic processing $[52,54]$.

Taken together, $\mathrm{Cu}$ has beneficial roles in the course of $\mathrm{AD}$ based on the following observations: (i) it promotes the non-amyloidogenic processing of APP and thereby lowers the $\mathrm{A} \beta$ production in cell culture systems, (ii) it increases lifetime and decreases soluble amyloid production in APP transgenic mice, and (iii) in a clinical trial with $\mathrm{AD}$ patients, 
the decline of $\mathrm{A} \beta$ levels in CSF, which is a diagnostic marker, is diminished. More research is urgently required to understand why there is an apparent disturbance in metal homeostasis in $\mathrm{AD}$ and how this disturbance can be addressed therapeutically.

\section{Abbreviations}

AD: $\quad$ Alzheimer's disease

APP: $\quad$ Amyloid precursor protein

BACE1: Beta-site APP cleaving enzyme 1

Cp: Ceruloplasmin

Cu: Copper

PBT2: Second-generation 8-hydroxy quinoline analog

SOD1: $\quad \mathrm{Cu}, \mathrm{Zn}$ superoxide dismutase

ADAScog: AD Assessment Scale, Cognitive subscale.

\section{References}

[1] S. Lutsenko, "Human copper homeostasis: a network of interconnected pathways," Current Opinion in Chemical Biology, vol. 14, no. 2, pp. 211-217, 2010.

[2] L. J. Harvey and H. J. McArdle, "Biomarkers of copper status: a brief update," British Journal of Nutrition, vol. 99, supplement 3, pp. S10-S13, 2008.

[3] C. Treiber, A. Simons, M. Strauss et al., "Clioquinol mediates copper uptake and counteracts copper efflux activities of the amyloid precursor protein of Alzheimer's disease," Journal of Biological Chemistry, vol. 279, no. 50, pp. 51958-51964, 2004.

[4] A. I. Bush, G. Multhaup, R. D. Moir et al., "A novel zinc(II) binding site modulates the function of the $\beta A 4$ amyloid protein precursor of Alzheimer's disease," Journal of Biological Chemistry, vol. 268, no. 22, pp. 16109-16112, 1993.

[5] L. Hesse, D. Beher, C. L. Masters, and G. Multhaup, "The $\beta$ A4 amyloid precursor protein binding to copper," FEBS Letters, vol. 349, no. 1, pp. 109-116, 1994.

[6] G. Multhaup, A. Schlicksupp, L. Hesse et al., "The amyloid precursor protein of Alzheimer's disease in the reduction of copper(II) to copper(I)," Science, vol. 271, no. 5254, pp. 14061409, 1996.

[7] G. Multhaup, T. Ruppert, A. Schlicksupp et al., "Copper-binding amyloid precursor protein undergoes a site-specific fragmentation in the reduction of hydrogen peroxide," Biochemistry, vol. 37, no. 20, pp. 7224-7230, 1998.

[8] K. M. Acevedo, Y. H. Hung, A. H. Dalziel et al., "Copper promotes the trafficking of the amyloid precursor protein," Journal of Biological Chemistry, vol. 286, no. 10, pp. 82528262, 2011.

[9] Y. H. Hung, E. L. Robb, I. Voltakis et al., "Paradoxical condensation of copper with elevated $\beta$-amyloid in lipid rafts under cellular copper deficiency conditions. Implications for Alzheimer disease," Journal of Biological Chemistry, vol. 284, no. 33, pp. 21899-21907, 2009.

[10] B. Angeletti, K. J. Waldron, K. B. Freeman et al., "BACE1 cytoplasmic domain interacts with the copper chaperone for superoxide dismutase-1 and binds copper," Journal of Biological Chemistry, vol. 280, no. 18, pp. 17930-17937, 2005.

[11] C. S. Atwood, X. Huang, R. D. Moir, R. E. Tanzi, and A. I. Bush, "Role of free radicals and metal ions in the pathogenesis of Alzheimer's disease," Metal ions in Biological Systems, vol. 36, pp. 309-364, 1999.

[12] A. Clements, D. Allsop, D. M. Walsh, and C. H. Williams, "Aggregation and metal-binding properties of mutant forms of the amyloid A $\beta$ peptide of Alzheimer's disease," Journal of Neurochemistry, vol. 66, no. 2, pp. 740-747, 1996.

[13] J. Dong, C. S. Atwood, V. E. Anderson et al., "Metal binding and oxidation of amyloid- $\beta$ within isolated senile plaque cores: raman microscopic evidence," Biochemistry, vol. 42, no. 10, pp. 2768-2773, 2003.

[14] M. A. Lovell, J. D. Robertson, W. J. Teesdale, J. L. Campbell, and W. R. Markesbery, "Copper, iron and zinc in Alzheimer's disease senile plaques," Journal of the Neurological Sciences, vol. 158, no. 1, pp. 47-52, 1998.

[15] A. I. Bush, W. H. Pettingell, G. Multhaup et al., "Rapid induction of Alzheimer A $\beta$ amyloid formation by zinc," Science, vol. 265, no. 5177, pp. 1464-1467, 1994.

[16] D. M. Walsh, I. Klyubin, J. V. Fadeeva et al., "Naturally secreted oligomers of amyloid $\beta$ protein potently inhibit hippocampal long-term potentiation in vivo," Nature, vol. 416, no. 6880, pp. 535-539, 2002.

[17] A. Harmeier, C. Wozny, B. R. Rost et al., "Role of amyloid- $\beta$ glycine 33 in oligomerization, toxicity, and neuronal plasticity," Journal of Neuroscience, vol. 29, no. 23, pp. 7582-7590, 2009.

[18] M. Jin, N. Shepardson, T. Yang, G. Chen, D. Walsh, and D. J. Selkoe, "Soluble amyloid $\beta$-protein dimers isolated from Alzheimer cortex directly induce Tau hyperphosphorylation and neuritic degeneration," Proceedings of the National Academy of Sciences of the United States of America, vol. 108, no. 14, pp. 5819-5824, 2011.

[19] L. X. Zhou, J. T. Du, Z. Y. Zeng et al., "Copper (II) modulates in vitro aggregation of a tau peptide," Peptides, vol. 28, no. 11, pp. 2229-2234, 2007.

[20] A. Soragni, B. Zambelli, M. D. Mukrasch et al., "Structural characterization of binding of $\mathrm{Cu}(\mathrm{II})$ to Tau protein," Biochemistry, vol. 47, no. 41, pp. 10841-10851, 2008.

[21] X. Huang, C. S. Atwood, M. A. Hartshorn et al., "The A $\beta$ peptide of Alzheimer's disease directly produces hydrogen peroxide through metal ion reduction," Biochemistry, vol. 38, no. 24, pp. 7609-7616, 1999.

[22] M. Innocenti, E. Salvietti, M. Guidotti et al., "Trace copper(II) or zinc(II) ions drastically modify the aggregation behavior of Amyloid- $\beta 1-42$ : an AFM study," Journal of Alzheimer's Disease, vol. 19, no. 4, pp. 1323-1329, 2010.

[23] S. Bolognin, L. Messori, D. Drago, C. Gabbiani, L. Cendron, and P. Zatta, "Aluminum, copper, iron and zinc differentially alter amyloid-A $\beta$ 1-42 aggregation and toxicity," International Journal of Biochemistry and Cell Biology, vol. 43, no. 6, pp. 877885, 2011.

[24] C. J. Maynard, R. Cappai, I. Volitakis et al., "Overexpression of Alzheimer's disease amyloid- $\beta$ opposes the age-dependent elevations of brain copper and iron," Journal of Biological Chemistry, vol. 277, no. 47, pp. 44670-44676, 2002.

[25] A. R. White, R. Reyes, J. F. B. Mercer et al., "Copper levels are increased in the cerebral cortex and liver of APP and APLP2 knockout mice," Brain Research, vol. 842, no. 2, pp. 439-444, 1999.

[26] T. A. Bayer, S. Schäfer, A. Simons et al., "Dietary Cu stabilizes brain superoxide dismutase 1 activity and reduces amyloid $\mathrm{A} \beta$ production in APP 23 transgenic mice," Proceedings of the National Academy of Sciences of the United States of America, vol. 100, no. 2, pp. 14187-14192, 2003.

[27] R. A. Cherny, C. S. Atwood, M. E. Xilinas et al., "Treatment with a copper-zinc chelator markedly and rapidly inhibits $\beta$-amyloid accumulation in Alzheimer's disease transgenic mice," Neuron, vol. 30, no. 3, pp. 665-676, 2001. 
[28] P. A. Adlard, R. A. Cherny, D. I. Finkelstein et al., "Rapid restoration of cognition in Alzheimer's transgenic mice with 8Hydroxy quinoline analogs is associated with decreased interstitial A $\beta$," Neuron, vol. 59, no. 1, pp. 43-55, 2008.

[29] N. G. Faux, C. W. Ritchie, A. Gunn et al., "PBT2 rapidly improves cognition in alzheimer's disease: additional phase II analyses," Journal of Alzheimer's Disease, vol. 20, no. 2, pp. 509 516, 2010.

[30] P. A. Adlard, L. Bica, A. R. White et al., "Metal ionophore treatment restores dendritic spine density and synaptic protein levels in a mouse model of Alzheimer's disease," PLoS One, vol. 6, no. 3, Article ID e17669, 2011.

[31] S. Schäfer, F. G. Pajonk, G. Multhaup, and T. A. Bayer, "Copper and clioquinol treatment in young APP transgenic and wildtype mice: effects on life expectancy, body weight, and metalion levels," Journal of Molecular Medicine, vol. 85, no. 4, pp. 405-413, 2007.

[32] D. L. Sparks and B. G. Schreurs, "Trace amounts of copper in water induce $\beta$-amyloid plaques and learning deficits in a rabbit model of Alzheimer's disease," Proceedings of the National Academy of Sciences of the United States of America, vol. 100, no. 19, pp. 11065-11069, 2003.

[33] D. L. Sparks, R. Friedland, S. Petanceska et al., "Trace copper levels in the drinking water, but not zinc or aluminum influence CNS Alzheimer-like pathology," Journal of Nutrition, Health and Aging, vol. 10, no. 4, pp. 247-254, 2006.

[34] D. L. Sparks, C. Ziolkowski, T. Lawmaster, and T. Martin, "Influence of water quality on cholesterol-induced tau pathology: preliminary data," International Journal of Alzheimer's Disease, vol. 2011, Article ID 987023, 7 pages, 2011.

[35] C. Marquer, V. Devauges, J. -C. Cossec et al., "Local cholesterol increase triggers amyloid precursor protein-Bacel clustering in lipid rafts and rapid endocytosis," Federation of American Societies for Experimental Biology Journal, vol. 25, no. 4, pp. 1295-1305, 2011.

[36] H. Kessler, F. G. Pajonk, D. Bach et al., "Effect of copper intake on CSF parameters in patients with mild Alzheimer's disease: a pilot phase 2 clinical trial," Journal of Neural Transmission, vol. 115, no. 12, pp. 1651-1659, 2008.

[37] H. Kessler, T. A. Bayer, D. Bach et al., "Intake of copper has no effect on cognition in patients with mild Alzheimer's disease: a pilot phase 2 clinical trial," Journal of Neural Transmission, vol. 115, no. 8, pp. 1181-1187, 2008.

[38] H. Kessler, F. G. Pajonk, P. Meisser et al., "Cerebrospinal fluid diagnostic markers correlate with lower plasma copper and ceruloplasmin in patients with Alzheimer's disease," Journal of Neural Transmission, vol. 113, no. 11, pp. 1763-1769, 2006.

[39] F. G. Pajonk, H. Kessler, T. Supprian et al., "Cognitive decline correlates with low plasma concentrations of copper in patients with mild to moderate Alzheimer's disease," Journal of Alzheimer's Disease, vol. 8, no. 1, pp. 23-27, 2005.

[40] C. W. Ritchie, A. I. Bush, A. Mackinnon et al., "Metal-protein attenuation with Iodochlorhydroxyquin (Clioquinol) targeting $\mathrm{A} \beta$ amyloid deposition and toxicity in Alzheimer disease: a pilot phase 2 clinical trial," Archives of Neurology, vol. 60, no. 12, pp. 1685-1691, 2003.

[41] L. Lannfelt, K. Blennow, H. Zetterberg et al., "Safety, efficacy, and biomarker findings of PBT2 in targeting $\mathrm{A} \beta$ as a modifying therapy for Alzheimer's disease: a phase IIa, double-blind, randomised, placebo-controlled trial," The Lancet Neurology, vol. 7, no. 9, pp. 779-786, 2008.

[42] R. Squitti, D. Lupoi, P. Pasqualetti et al., "Elevation of serum copper levels in Alzheimer's disease," Neurology, vol. 59, no. 8, pp. 1153-1161, 2002.
[43] R. Squitti, P. Pasqualetti, E. Cassetta et al., "Elevation of serum copper levels discriminates Alzheimer's disease from vascular dementia," Neurology, vol. 60, no. 12, pp. 2013-2014, 2003.

[44] R. Squitti, P. Pasqualetti, G. Dal Forno et al., "Excess of serum copper not related to ceruloplasmin in Alzheimer disease," Neurology, vol. 64, no. 6, pp. 1040-1046, 2005.

[45] R. Squitti, G. Barbati, L. Rossi et al., "Excess of nonceruloplasmin serum copper in AD correlates with MMSE, CSF $\beta$ amyloid, and h-tau," Neurology, vol. 67, no. 1, pp. 76-82, 2006.

[46] N. Arnal, D. O. Cristalli, M. J. T. de Alaniz, and C. A. Marra, "Clinical utility of copper, ceruloplasmin, and metallothionein plasma determinations in human neurodegenerative patients and their first-degree relatives," Brain Research, vol. 1319, no. C, pp. 118-130, 2010.

[47] G. J. Brewer, S. H. Kanzer, E. A. Zimmerman, D. F. Celmins, S. M. Heckman, and R. Dick, "Copper and ceruloplasmin abnormalities in Alzheimers disease," American Journal of Alzheimer's Disease and other Dementias, vol. 25, no. 6, pp. 490-497, 2010.

[48] Z. L. Harris, A. P. Durley, T. K. Man, and J. D. Gitlin, “Targeted gene disruption reveals an essential role for ceruloplasmin in cellular iron efflux," Proceedings of the National Academy of Sciences of the United States of America, vol. 96, no. 19, pp. 10812-10817, 1999.

[49] S. Bucossi, M. Ventriglia, V. Panetta et al., "Copper in alzheimer's disease: a meta-analysis of serum,plasma, and cerebrospinal fluid studies," Journal of Alzheimer's Disease, vol. 24, no. 1, pp. 175-185, 2011

[50] M. P. Cuajungco, K. Y. Fagét, X. Huang, R. E. Tanzi, and A. I. Bush, "Metal chelation as a potential therapy for Alzheimer's disease," Annals of the New York Academy of Sciences, vol. 920, pp. 292-304, 2000.

[51] C. Treiber, M. A. Quadir, P. Voigt et al., "Cellular copper import by nanocarrier systems, intracellular availability, and effects on amyloid $\beta$ peptide secretion," Biochemistry, vol. 48 , no. 20, pp. 4273-4284, 2009.

[52] T. Borchardt, J. Camakaris, R. Cappai, C. L. Masters, K. Beyreuther, and G. Multhaup, "Copper inhibits $\beta$-amyloid production and stimulates the non-amyloidogenic pathway of amyloid-precursor-protein secretion," Biochemical Journal, vol. 344, no. 2, pp. 461-467, 1999.

[53] A. L. Phinney, B. Drisaldi, S. D. Schmidt et al., "In vivo reduction of amyloid- $\beta$ by a mutant copper transporter," Proceedings of the National Academy of Sciences of the United States of America, vol. 100, no. 24, pp. 14193-14198, 2003.

[54] M. A. Cater, K. T. McInnes, Q. X. Li et al., "Intracellular copper deficiency increases amyloid- $\beta$ secretion by diverse mechanisms," Biochemical Journal, vol. 412, no. 1, pp. 141-152, 2008. 


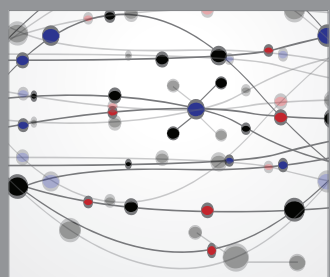

The Scientific World Journal
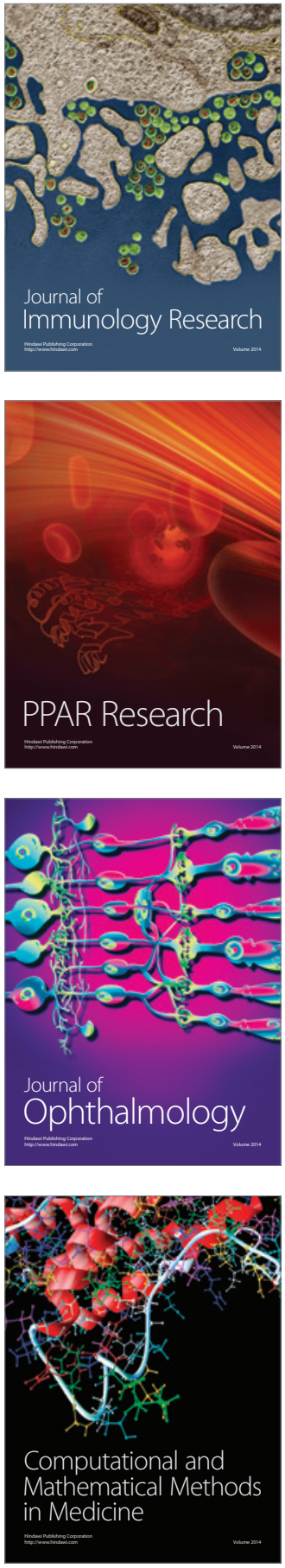

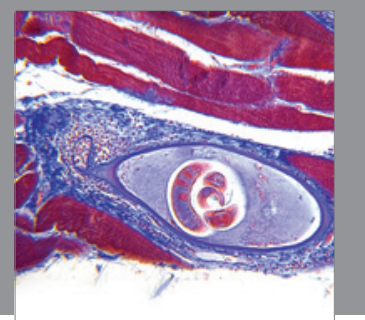

Gastroenterology

Research and Practice
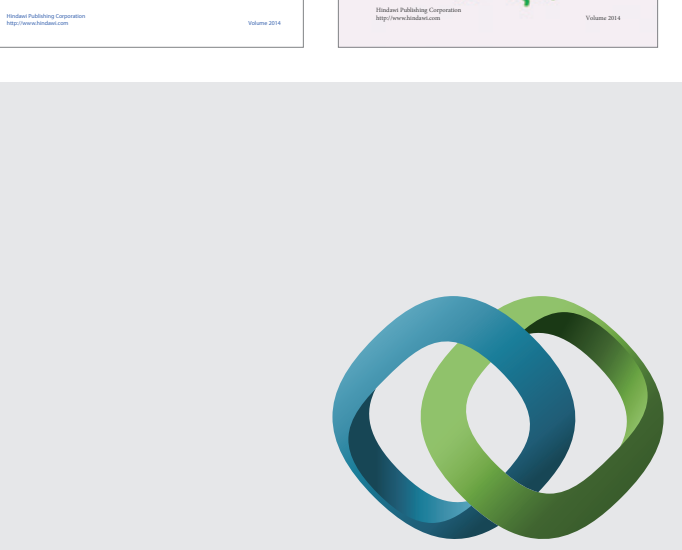

\section{Hindawi}

Submit your manuscripts at

http://www.hindawi.com
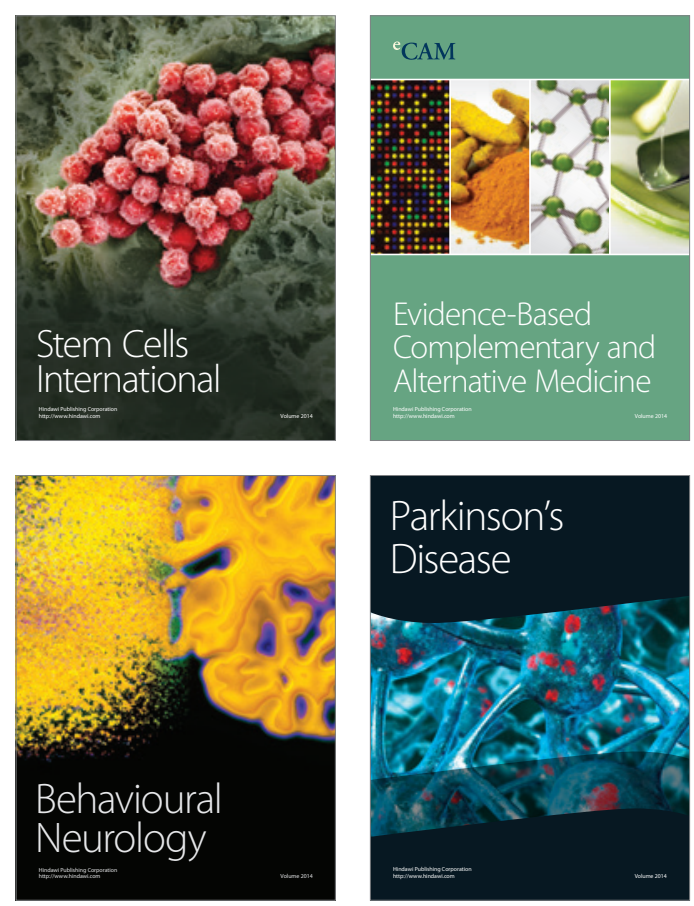

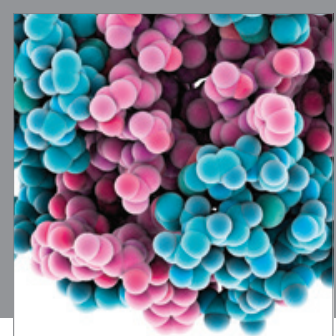

Journal of
Diabetes Research

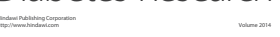

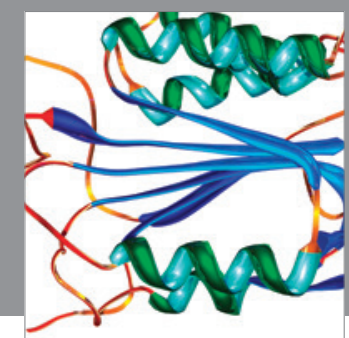

Disease Markers
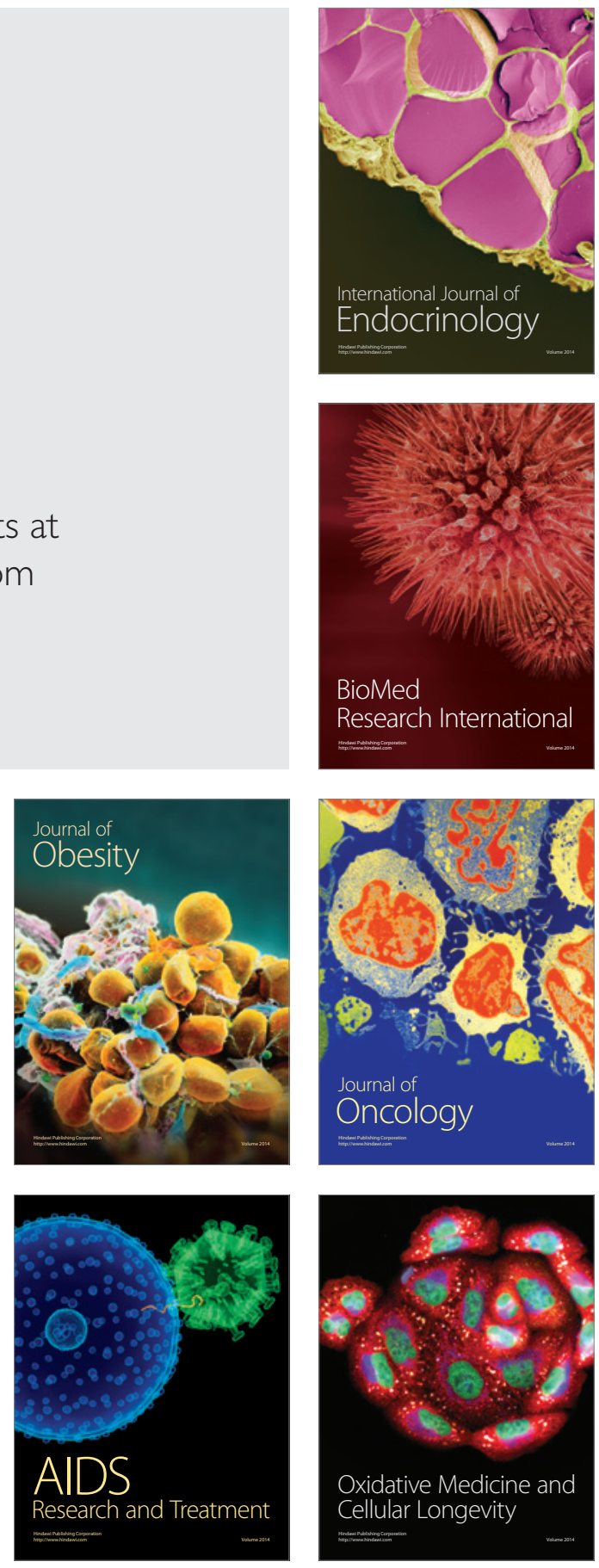